\begin{tabular}{|c|}
\hline FINAL DRAFT \\
Recherches en sciences de gestion - Management Sciences - \\
Ciencias de Gestión \\
$\mathrm{N}^{\circ} 133$, pp. 160-193
\end{tabular}

\title{
A polycentric view of coordination in extreme action teams: Insights from pre-hospital emergency teams
}

\section{Cécile Godé (Corresponding author)}

Full Professor in management science

Aix Marseille Univ, CRET-LOG, Aix-en-Provence, France

cecile.gode@univ-amu.fr

\section{Pauline Lenesley}

$\mathrm{PhD}$ in management science

Université Lyon 2, COACTIS EA 4161

paulinelenesley@hotmail.fr

\section{Valérie Buthion}

Assistant professor in management science

Université Claude Bernard, LSAF EA 2429

valerie.buthion@univ-lyon1.fr

\begin{abstract}
Our article addresses the following research question: how does a polycentric view refine our understanding of interconnections between coordination practices and macro-arrangements in extreme action teams? It examines coordination between French pre-hospital emergency teams. It reveals three main coordination practices and disclose how macro-arrangements provide teams with a permanent template for coordinating in turbulent situations.
\end{abstract}


Keywords Coordination, extreme action teams, polycentric, practices, pre-hospital emergency

Titre : La coordination polycentrique dans les équipes extrêmes : le cas d'équipes d'urgence préhospitalières

Résumé : Cet article pose la question de recherche suivante : comment la polycentricité permet-elle d'affiner notre compréhension des liens entre les pratiques de coordination et les macro-arrangements dans les équipes extrêmes? Il analyse la coordination entre des équipes d'urgence préhospitalières. Les résultats décrivent trois pratiques de coordination et démontrent que les macro-arrangements offrent aux équipes extrêmes une structure permanente de coordination.

Mots clés Coordination, équipes extrêmes, polycentrique, pratiques, secours d'urgence préhospitalier

Título: Coordinación policéntrica en equipos extremos: el caso de los equipos de emergencia prehospitalaria

Resumen: Este artículo plantea la siguiente pregunta de investigación: ¿cómo una visión policéntrica refinar nuestra comprensión de las interconexiones entre las prácticas de coordinación y los macroarreglos en los equipos de acción extrema? El examina la coordinación entre los equipos de emergencia prehospitalarios franceses. Revela tres prácticas principales de coordinación y cómo los macro-arreglos proporcionan a los equipos una plantilla permanente para coordinar en situaciones turbulentas.

Palabras claves Coordinación, equipos de acción extrema, policéntrico, prácticas, emergencia prehospitalaria 
While coordination has been a central topic in research for years, our understanding is still messy and fragmented (Okhuysen and Bechky, 2009). That drove scholars to further investigate coordination within a practice-based view to examine the emergent and situated nature of coordination (e.g. Faraj and Xiao, 2006; Bechky, 2006; Jarzabkowski et al., 2012; Harrison and Rouse, 2014; Wolbers et al., 2018). These more recent studies define coordination as a "temporally unfolding and contextualized process of input regulation and interaction articulation to realize a collective performance" (Faraj and Xiao, 2006, p. 1157).

Among these practice-based contributions, many investigate extreme action teams, defined as "highly skilled members [who] cooperate to perform urgent, unpredictable, interdependent and highly consequential tasks while simultaneously coping with frequent change in team's composition and training their team's novices members" (Klein et al., 2006, p. 590). For instance, authors investigate coordination practices in police forces (Schakel et al., 2016), military squadrons (Godé and Lebraty, 2015), emergency response groups (Majchrzak et al., 2007; Wolbers et al., 2018), or emergency trauma centre teams (Faraj and Xiao, 2006). While all teams in organizations need effective coordination to perform, extreme action teams more frequently deal with uncertainty and hence possibly require proper coordination practices for encountering unexpected situations and enabling adaptation (Godé, 2015; Bouty et al., 2011). In investigating extreme action teams, coordination-as-practice contributions make coordination transparently observable (Weick and Sutcliffe, 2007, p. 64 ), and provide a rich body of updated knowledge regarding the way it is is daily developed and practiced.

Although significant advances, this fruitful body of research partially addresses the question of micro-macro connections on coordination practices. As extreme teams are used to work "within a larger institutional network of organizations, communities, and individuals" (Majchrzak et al., 2007, p. 159), more studies are needed to capture the complex and imbricated organizational contexts these teams handle to perform. Adopting a polycentric view of coordination, our article aims to address this gap by analysing the interconnections between coordination practices developed by extreme teams and macroarrangements they daily deal with.

Defined as "many centres of decision making that are formally independent of each other [and, meanwhile] take each other into account in competitive relationships, enter into various contractual and cooperative undertakings or have recourse to central mechanisms to resolve conflicts" (Ostrom et al., 1961, pp. 831-2), the concept of polycentricity directs attention to the examination of micro- interactions 
in broader field settings, taking into consideration multitype and multilevel arrangements. In this article, we suggest that the concept of polycentricity may allow grasping the micro-macro arrangements of coordination, as it exposes processes and issues that may remain hidden with a single micro-level analysis.

This prompts the following research question: How does a polycentric view refine our understanding of interconnections between coordination practices and macro-arrangements in extreme action teams? To address our question, we conducted an ethnomethodology research to examine these complex issues in real-life setting. Our qualitative study involves different French Pre-Hospital Emergency (PHE) teams. PHE teams consist of multiple rescue teams which work under time-speed pressures and regularly face with unexpected situations. They must coordinate with each other in polycentric settings, as they report to different decision centres and may implement different rules, procedures and material conditions into practices.

Our analysis demonstrates that polycentricity is a relevant approach to delve into the interconnections between macro-arrangements and teamwork practices when extreme teams coordinate. It first allows revealing three main coordination practices - anticipation, negotiation and consensus - developed by extreme teams as they coordinate. It also helps to disclose how macro-arrangements provide extreme teams with a permanent template for coordinating, enable them to both structure teamwork and dynamically adjust to situated situations and unexpected events. Finally, our findings suggest some leads for practice, as a polycentric view of coordination offers potential for improving performance both for PHE teams and traditional teams in organisational settings.

The remainder of the article is structured as follow: the first section reviews practice-based contributions on coordination within and between extreme action teams and presents the concept of polycentricity. The second section exposes the research setting, the ethnomethodology research we adopted, and describes two different action situations involving French PHE teams. The third section finally analyses our findings and discusses theoretical contributions and practical insights for organisations.

\section{Conceptual framing}

\section{Coordination practices in extreme action teams}

Practices are "routinized type of behavior which consists of several elements, interconnected to one other: forms of bodily activities, forms of mental activities, 'things' and their use, a background knowledge in the form of understanding, know-how, states of emotion and motivational knowledge" (Reckwitz, 2002, pp. 49-50). They are the 
manner of working to achieve a task (Bourdieu, 1980), emerging from "an ongoing stream of activities and enact[ing] through the contextualized actions of individuals" (Faraj and Xiao, 2006, p. 1157). Practice-based theory directs attention to what people do in their everyday and situated organizing. Embracing this focus, coordinationas-practices research provide micro-level insights by exploring how coordination is concretely enacted by actors through their dynamic social activities (Jarzabkowski et al., 2012). Coordination is an emergent and situated phenomena, unfolding in specific times and spaces, and resulting of particular conditions during which actors interact to achieve collective outcomes.

Given the features of practices, Nicolini, Gherardi and Yanow (2003) argue that they are "better observed when some "breakdown" occurs in [...] entrenched practice[s] or when some substantial change requires major realignments of the extant configuration of practice [s]" (p. 28). Many coordination-as-practice contributions answer the authors' call in examining practices when coordination is performed by extreme action teams (e.g. Wolbers et al., 2018; Schakel et al., 2016; Majchrzak et al., 2007; Faraj and Xiao, 2006). Authors delve deeper into the complexity of coordination in investigating how these teams generate multiple practices to accomplish a task and respond quickly to unexpected turns of events.

For example, analysing how medical teams coordinate in a US Trauma Centre, Faraj and Xiao (2006) demonstrate that coordination is based on expertise and dialogic practices. Expertise practices ensure expertise integration and flexible teamwork. Dialogic practices, for their part, operates to guarantee timely and situated responses to unexpected events. The authors especially emphasize that, when faced with uncertainty, organisations must create room for dialogic coordination practices, through which actors build sense-making and challenge protocols. In a close spirit, Godé and Lebraty (2015) investigate experience feedback as a way to foster team coordination and adaptation facing the unexpected. Building on the case of an aerobatic military team, the authors demonstrate that experience feedback improves coordination in promoting the articulation of three coordination practices: communication, socialization and reflexivity. More recently, Schakel, Van Fenema and Faraj (2016) examine the challenge posed by unexpected switching between practices in fastresponse organisations. Relying on multiple specialized police teams handling a Dutch National Police operation, they state that fastresponse teams experience some difficulties to switch from a practice (surveillance) to another (apprehension) as they are already committed (in terms of roles, routines, collective sense-making, material 
arrangements and field conditions) to a specific practice. Finally, the latest Wolbers, Boersma and Groenewegen article (2018) analyses coordination practices developed during emergency response operations by a team consisting of fire department, medical services, and police officers. The authors found that, confronting to turbulent situations, these officers use three interrelated practices: working around procedures, delegating tasks, and demarcating expertise. In creating fragmentation rather integration, these coordination practices support flexibility, improvisation and ad-hoc responses required to handle the unforeseen.

Altogether, these contributions approach coordination as bundles of practices. The authors demonstrate that extreme action teams develop manifold situated coordination practices regarding the specific circumstances they handle (Bouty et al., 2011). The authors also describe the complex and imbricated nature of organizational settings extreme teams are involved in (e.g. multiple specialized police teams in the Schakel et al.'s article; fire department, medical services, and police officers in the Wolbers et al.'s article). However, they do not go deeper into the comprehension of these broader field settings. While they notice the connections between macro-arrangements and coordination practices, they tend to overlook this question in their findings. For example, Majchrzak, Jarvenpaa and Hollingshead (2007) argue that members from emergency response teams approach situations to handle from specific social, institutional and organisational rules, which may be different from one participant to another. Authors assume that these diversities "may affect not only trust [among emergency response team members], but the speed of forming groups, role negotiation, and interaction patterns" (p. 159). However, they do not go further to examine these impacts on coordination. Another example is provided by Godé and Lebraty (2015) who highlight that, beyond their dedicated aerobatic missions, team members are tightly engaged in military duties, attitudes and cultural values. The aerobatic military team also deals with the Fédération Aéronautique International (FAI) - in charge of publishing competition rules and procedures, organizing national and international Championships, etc. - and private sponsors which fund a part of their communication activities. These multiple networks and partners create an intricately macro-context which is underplayed by the authors in their study of coordination practices. A last example can be found in the Schakel, Van Fenema and Faraj (2016)'s contribution. The authors report a Police operation imbricated into a complex institutional and physical environment of which disconnections may challenge the coordination practices switching. They describe a multidisciplinary Police operation which involves several Police units 
and specialists, reporting to three different teams (visual, technical, and helicopter). The article also mentions the role played by the Police chief, the National Police Agency and the Dutch Parliament after the police operation failure. However, while acknowledging that institutional disconnects have laid to underperforming outcomes, the authors do not question these macro-arrangements complexities on coordination practices.

In this article, we suggest that the polycentric perspective is an appropriated way to refine our understanding of the interconnections between micro and macro-arrangements extreme action teams daily deal with in their continuous efforts of coordination.

\section{The concept of polycentricity}

The concept of polycentricity can be defined as "a structural feature of social systems of many decision centers having limited and autonomous prerogatives and operating under an overarching set of rules" (Aligica and Tarko, 2012, p. 237). Polanyi (1951) was the first to develop the contour of this concept. The author was interested in social organizations (e.g. scientific communities, the market, etc.) where actors interact freely within a general system of rules and norms. Drawing on Polanyi, Vincent and Elinor Ostrom (e.g. Ostrom et al., 1961; Ostrom, 2005) offer the full import of the concept of polycentricity, providing a complete theoretical development linked to empirical substance. They consider polycentricity as a complex form of governance, with overlapping centers of decision operating with some degree of autonomy. As argue by Ostrom (2010), polycentric settings are "multiple governing authorities at differing scales [...]. Each unit within exercises considerable independence to make norms and rules within a specific domain" (Ostrom, 2010, p. 552).

As such, the concept of polycentricity allows analysing an interwoven system of power, decision-makings, rules and material conditions that gathers different individual and collective actions, in complex multilevel interdependent relationships (Aligica and Tarko, 2012). In a polycentric setting, teams belong to formally different decision structures and follow an overarching system of rules, procedures and norms. They are collectively involved in diverse ways of providing outcomes and achieving joint actions.

Consequently, as Ostrom shows, the concept of polycentricity allows building a complex theoretical view - instead of a "dichotomous world of the market and the state" (Ostrom, 2009, p. 408) - to explain the puzzling of interactions and problem-solving teams are involved in. As she claimed during her Nobel Prize Lecture: "the humans [...] have complex motivational structures and establish diverse private-forprofit, governmental, and community institutional arrangements that 
operate at multiple scales" (Ostrom, 2009, p. 408). She considers that the appropriate analytical level is the one that provides a deeper understanding of the multiplicity of teams and affiliations involved in the collective process of working and producing outputs.

For example, examining the impact of governance arrangements for policing within 80 U.S. metropolitan areas, Ostrom and her-co-authors (e.g., Ostrom, 1972; Ostrom and Whitaker, 1973, Ostrom et al., 1978) study a series of case comparisons of Police departments to assess the performance of direct (e.g. patrols, traffic control, investigations) and intermediate (e.g. criminal laboratory facilities, communication dispatching) services to citizen. Digging into the practices through which police forces deliver these services on the ground, the authors demonstrate that "metropolitan areas with large numbers of autonomous direct service producers achieve higher level of efficiency. Efficiency was also enhanced in those metropolitan areas with a small number of producers providing indirect services" (Ostrom and Ostrom, 2014, p. 171). Ostrom's and colleagues research reveals that polycentric settings are efficiently governed through a wide diversity of micro and macro-arrangements, which make extreme actions teams (such as police teams they study) resilient and reactive.

The concept of polycentricity offers a fruitful perspective to explore the interconnections between micro and macro-arrangements in extreme action team coordination. Coordination practices cannot be examined in isolation as they are always immersed in complex texture of interconnections (Nicolini, 2009). Their analysis both requires a focus on local practices developed by actors and an appreciation of their connections to broader field settings such as organizational rules, norms and procedures. In this article, we suggest that the concept of polycentricity opens a new space to examine coordination practices when extreme action teams are engaged in the same collective outcome while they report to different decision-making centres and follow an overarching system of rules.

\section{Research setting and methods}

Our empirical study is based on a research agreement between one of the authors university and the "Manche" Fire Rescue Department (FRD). The "Manche" FRD handles multiple emergency interventions, from sea rescue operations (the connection between North Sea and Atlantic Ocean leads to a severe maritime traffic) to people assistance. In this article, we investigate a specific type of extreme teams, called Pre-Hospital Emergency (PHE) teams, for which the "Manche" FRD takes part in its constitution. PHE teams cover a wide range of paramedical and medical operations. Their aim is to provide victims with an urgent and unscheduled care provision outside of the hospital, 
from minor injury to life threatening injury. PHE teams are engaged in care-giving both on-scene and in-transit to the hospital. They consist of a body of diverse prehospital practitioners, who are temporarily put together by emergency dispatchers. When a victim calls for a rescue (the French emergency phone numbers are 15, 18 and 112), the dispatcher identifies the injury level, asks for a distant first diagnosis to a regulation doctor when necessary (in order to advance PHE team interventions) and deploys appropriated resources (composition of PHE teams and transportation means). From first-aiding to medical competences, PHE teams consist of diverse prehospital expertise that get together to achieve an emergency care provision operation (see Figure 1).

Figure 1. The Pre-Hospital Emergency (PHE) teams

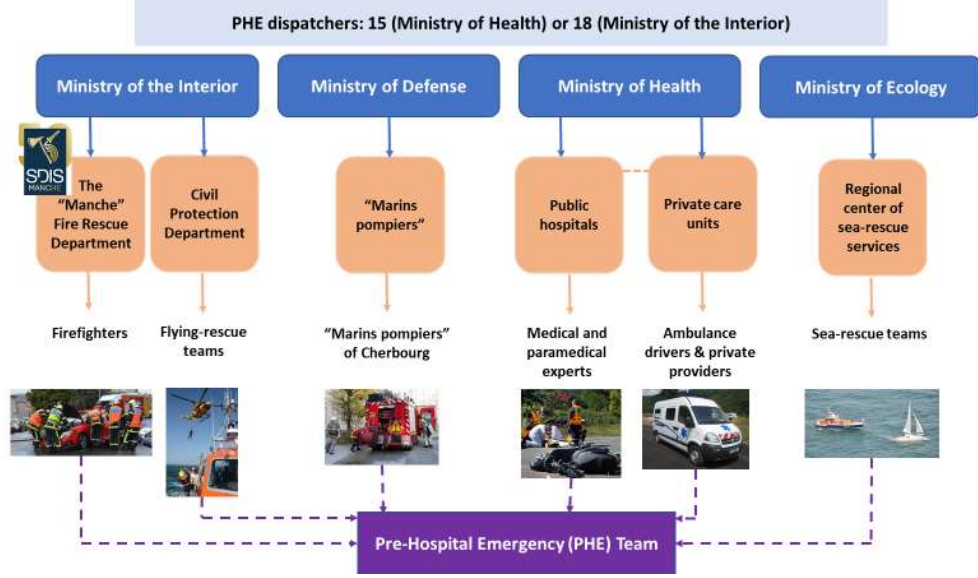

Our empirical investigation is based on the interpretative framework of ethnomethodology. Garfinkel (1967) introduces ethnomethodology as a way to focus on action and doing, in describing how actors "produce and manage settings of organized everyday affairs" (Garfinkel 1967, p. 1). As the author insists on, it is crucial to analyse both the situated actions of people and the sequence of these situated actions to understand how practices emerge from daily activities and, in turn, generate and reproduce the social order. Ethnomethodology directs our analytical focus on practical activities and circumstances in which macro-arrangements are rendered visible and put into practice when extreme teams coordinate. It helps us to study how extreme teams understand and create the social order (here, coordination) when they perform under uncertainty and time pressure. Consequently, one way to answer our research question - How does a polycentric view refine our understanding of interconnections between coordination practices and 
macro-arrangements in extreme action teams? - is to conduct an ethnomethodological research (Horvath and Datry, 2013).

Data collection primarily relies on participant observations, enabling to get close to action situations. An action situation refers to situation in which two or more actors select actions, engage in patterns of interaction, and realize collective outcomes from their interactions. From July 1 to October 15, 2016, we observed 18 pre-hospital action situations with a maximum variation in terms of: distance from the closest relevant hospital, team composition (professionals and/or volunteers), actors from different centres of decision, night and day operations, localizations, week, week-end and holidays interventions, national and local social events, different kind of medical emergency (see Table 1).

For each action situation, one of the authors of this article was embedded in a rescue team vehicle, observing coordination "on action and doing" during real-life emergency operations. She was particularly alert to all coordination challenges she could observe, with a special focus on coordination practices and macro-arrangements (rules, norms, procedures, core values, and material conditions) put into practice by actors. She closely examined what people actually did when they coordinated, keeping and up-dating a field-diary day after day. Finally, she collected procedures used by teams, gathered the notes they wrote during and after operations, and transcribed radio communications between them.

Table 1. Collected action situations 


\begin{tabular}{|c|c|c|c|c|}
\hline Action situation & Date (2016) & Intervention & Actors on scene & $\begin{array}{l}\text { Coordination challenges } \\
\text { and unexpected events }\end{array}$ \\
\hline $\begin{array}{l}\text { No1. Saint Lô Saint } \\
\text { George }\end{array}$ & $07 / 01,08.39 \mathrm{am}$ & Epigastric discomfort - at home & $\begin{array}{l}1 \text { dispatcher, } 1 \text { regulation doctor, } 3 \\
\text { firefighters }(1 \text { professional and } 2 \text { first- } \\
\text { aider volunteers) }\end{array}$ & Unclear emergency localisation \\
\hline $\mathbf{N}^{\circ} 3$. Couvains & $07 / 01,04.47 \mathrm{pm}$ & $\begin{array}{l}4 \text { serious casualties due to two- } \\
\text { vehicle accidents - public road }\end{array}$ & $\begin{array}{l}1 \text { dispatcher, } 1 \text { regulation doctor, } 2 \text { police } \\
\text { officers, } 3 \text { professional firefighters, } 1 \text { team } \\
\text { leader firefighter and } 2 \text { firefighters } \\
\text { specialized at auto-extrication }\end{array}$ & $\begin{array}{l}\text { Unclear first distant diagnosis, teams involved outside } \\
\text { their regular sector }\end{array}$ \\
\hline ํ⒌ Cherbourg & $07 / 03,04.15 \mathrm{pm}$ & $\begin{array}{l}\text { Little boy headache and vomiting } \\
\text { due to an accidental fall - public } \\
\text { road during the Tour de France }\end{array}$ & $\begin{array}{l}\text { Operational headquarter (prefectural, } \\
\text { local, police, etc. authorities), security } \\
\text { command post, professional firefighters } \\
\text { (including nurses and doctors), volunteer } \\
\text { firefighters (first-aiders), civil safety first- } \\
\text { aiders and police forces }\end{array}$ & $\begin{array}{l}\text { Dense crowd, problems for getting to the victim, many } \\
\text { ways of transportation, many decision-making layers, } \\
\text { higher rank decision makers involved in tactical } \\
\text { decision }\end{array}$ \\
\hline N7. Chausey & $07 / 12,06.37 \mathrm{pm}$ & $\begin{array}{l}\text { Shoulder and knee trauma due to } \\
\text { an accidental fall - public area }\end{array}$ & $\begin{array}{l}1 \text { dispatcher, } 1 \text { regulation doctor, } 2 \\
\text { firefighters (first-aider volunteer) and a } \\
\text { flying rescue team }\end{array}$ & $\begin{array}{l}\text { Difficult meteorological and environmental conditions, } \\
\text { helicopter transportation, delicate evacuation }\end{array}$ \\
\hline $\begin{array}{l}\text { No8. Saint Jean de } \\
\text { Daye }\end{array}$ & $07 / 27,12.27 \mathrm{pm}$ & $\begin{array}{l}\text { Allergic reaction after receiving a } \\
\text { medication - at home }\end{array}$ & $\begin{array}{l}1 \text { dispatcher, } 1 \text { regulation doctor, } 3 \\
\text { firefighters (1 professional, } 2 \text { first-aider } \\
\text { volunteers) and } 1 \text { firefighter nurse }\end{array}$ & $\begin{array}{l}\text { Unclear first distant diagnosis, once on site: no life } \\
\text { threatening, information sharing problems between the } \\
\text { nurse, firefighters and dispatcher }\end{array}$ \\
\hline $\begin{array}{l}\text { No9. Mont Saint } \\
\text { Michel }\end{array}$ & $07 / 29,10.22 \mathrm{am}$ & Attack of faintness - on the street & $\begin{array}{l}1 \text { dispatcher, Mont Saint Michel security } \\
\text { command post (14 first-aiders) and } 3 \\
\text { firefighters ( } 2 \text { first-aiders volunteers and } 1 \\
\text { nurse) }\end{array}$ & $\begin{array}{l}\text { Difficult environmental conditions, once on site: the } \\
\text { situation does not require an emergency operation }\end{array}$ \\
\hline $\mathbf{N}^{\circ}$ 10. Tribehou & $07 / 29,02.03 \mathrm{pm}$ & $\begin{array}{l}\text { General health deterioration of a } \\
\text { hemiplegic patient - at home }\end{array}$ & $\begin{array}{l}1 \text { dispatcher, } 1 \text { regulation doctor, } 1 \\
\text { general practitioner, } 1 \text { home care assistant, } \\
3 \text { firefighters ( } 1 \text { professional and } 2 \\
\text { volunteer first-aiders), and } 1 \text { hospital } \\
\text { nurse }\end{array}$ & $\begin{array}{l}\text { Unclear first distant diagnosis, dispatcher decision } \\
\text { (ambulance deficiency) questioned by firefighters, } \\
\text { different languages, different protocols and norms }\end{array}$ \\
\hline
\end{tabular}




\begin{tabular}{|c|c|c|c|c|}
\hline $\begin{array}{l}\text { No11. Cherbourg } \\
\text { Cité de la mer }\end{array}$ & $08 / 03,02.21 \mathrm{pm}$ & $\begin{array}{l}\text { Strong back pain and loss of } \\
\text { consciousness in a museum - public } \\
\text { area }\end{array}$ & $\begin{array}{l}1 \text { dispatcher, } 1 \text { regulation doctor, } 3 \\
\text { professional firefighters and a security } \\
\text { guard }\end{array}$ & $\begin{array}{l}\text { Dense crowd (many tourists on site), problems for } \\
\text { getting to the victim }\end{array}$ \\
\hline $\mathrm{N}^{\circ}$ 13. Saint Briac & $08 / 27,04.35 \mathrm{am}$ & $\begin{array}{l}\text { Accidental fall in the rocks - } \\
\text { bottom of a cliff }\end{array}$ & $\begin{array}{l}2 \text { dispatchers from different services, } 3 \\
\text { firefighters ( } 1 \text { professional nurse and } 2 \\
\text { first-aider volunteers) and a flying rescue } \\
\text { team from the civil protection }\end{array}$ & $\begin{array}{l}\text { Difficult environmental conditions, problems of } \\
\text { transportation, sensitive evacuation, different firefighter } \\
\text { rescue departments }\end{array}$ \\
\hline $\mathrm{N}^{\circ}$ 14. Ferry & $10 / 06,11.36 \mathrm{pm}$ & $\begin{array}{l}\text { Broken bone stuck in an old man } \\
\text { throat while a ferry ride - at sea }\end{array}$ & $\begin{array}{l}3 \text { regulators doctors from } 3 \text { different } \\
\text { services, the ferry nurse, a flying rescue } \\
\text { team and } 3 \text { professional firefighters }\end{array}$ & $\begin{array}{l}\text { Helicopter transportation under specific environmental } \\
\text { conditions, debate between } 3 \text { different authorities to } \\
\text { establish diagnosis and medical care, lack of info. for } \\
\text { hospital teams }\end{array}$ \\
\hline $\mathrm{N}^{\circ} 15$. Condé & $10 / 08,01.10 \mathrm{pm}$ & $\begin{array}{l}\text { General health deterioration - at } \\
\text { home }\end{array}$ & $\begin{array}{l}1 \text { dispatcher, } 1 \text { regulation doctor, } 1 \text { private } \\
\text { nurse, } 2 \text { firefighters (first-aider volunteers) } \\
\text { and a support team of } 3 \text { firefighters (first- } \\
\text { aider volunteers) }\end{array}$ & $\begin{array}{l}\text { Many PHE teams on scene, problem of information } \\
\text { sharing }\end{array}$ \\
\hline $\mathrm{N}^{\circ}$ 18. Agneaux & $10 / 14,08.11 \mathrm{pm}$ & $\begin{array}{l}\text { Old woman chest pain with trouble } \\
\text { breathing - at home }\end{array}$ & $\begin{array}{l}1 \text { dispatcher, } 1 \text { regulator doctor, } 3 \\
\text { firefighters ( } 2 \text { professional and } 1 \text { first- } \\
\text { aider volunteer) }\end{array}$ & $\begin{array}{l}\text { Unclear first distant diagnosis, difficulties to gather } \\
\text { appropriate medical information, emergency (for a } \\
\text { second patient) once at the hospital }\end{array}$ \\
\hline
\end{tabular}


Narratives have been written for each observed action situation in order to provide a deep description of coordination "on action and doing", and to bring out the interwoven practices and macro-arrangements when PHE teams achieve emergency care provision operations.

From the 18 action situations collected, we selected two as they allow for cross-narratives comparisons and examination of complex issues in real-life setting. The first action situation (Utah Beach, Tour de France, action situation $\mathrm{N}^{\circ} 4$ ) occurs during a famous cycling race during which PHE teams must handle a spectator accidental fall; the second action situation (Tribehou, action situation $\mathrm{N}^{\circ} 10$ ) occurs in Carentan's swamps where a PHE team is sent for a hemiplegic patient fast medical care. We selected these situations as they gather many coordination challenges commonly adressed by PHE teams during the other action situations we observed (see Table 1). Moreover, during the Utah Beach situation, PHE teams deal with an unforsseen event while everything runs smoothly during the Tribehou situation. Confronting these two situations was a way to observe potential differences in coordination processes when teams are confronted to the unexpected, and when they are not.

\section{Findings}

\section{The Utah Beach, Tour de France action situation}

During Summer 2016, the famous Tour de France cycling race goes from the Mont Saint Michel to Cherbourg. Widely covered by the media, it is followed by hundred thousand of people set along on roadsides to watch cyclists go by. Regarding terrorist threats, stampedes and faintness risks, police forces and PHE teams (from FRD, hospital, civil protection, non-profit organisations, etc.) are deployed for preventive purposes all along the route. The main goal is to provide emergency support and assistance as closely as possible to potential victims.

An operational headquarter is established at Cherbourg. It gathers higher rank decision makers from the Prefecture of the "Manche" as well as the FRD director. They aim at consolidating information and coordinating tactical headquarters. They benefit from a direct link with emergency dispatchers and regulator doctors $(15,18$ or 112 emergency number). An advanced medical post, consisted of medical and paramedical emergency experts and firefighters, is organised near the operational headquarter to gather, categorise and evacuate serious injured victims to hospital (if needed, the nearest hospital being at $40 \mathrm{mn}$ of the cycling race localisation). The operational headquarter is connected by radio with tactical headquarters: FRD, police, civil protection, non-profit organisations are each represented by a dedicated tactical headquarter, established in rescue trucks. Upon request by the 
operational headquarter, these tactical headquarters gather information from many emergency stations (professional and volunteer firefighters, volunteer first-aiders from non-profit organisations, etc.) localized on roadsides, coordinate first-aiders and ask for transfer to the advanced medical post if appropriated. Many ambulances are situated near the emergency stations and the advanced medical post.

To ensure cyclists' security and according to the race committee, crossing roads must be restricted, even in case of emergency. The operational headquarter produced a permanent emergency assistance map showing few "cutting points", that is localized spots where PHE teams can cross the road and organise ambulances access to victims without disrupting the cycling race. The map is shared by operational and tactical headquarters. Trainings were conducted to make sure that every PHE actor knows the shared map coding and the exact codes and position of cutting points.

July 2, 2016, $05.19 \mathrm{pm}$. An accident occurs during arrival of the peloton at Utah Beach. A policeman situated on the side of the cycle route is alerted by first-aiders who saw a person collapse in the crowd. Neither first-aiders nor the policeman have access to the victim. The policeman calls the operational headquarter, which immediately contacts the FRD tactical headquarter to ask for the distress exact localisation. It is easily found thanks to the map-code provided by the policeman. The FRD tactical headquarter consists of a head doctor, an emergency operations commander, a dispatcher and a nurse; all of them are firefighters. They follow their usual procedure called "graduated response", which specifies that a first diagnosis must be established by first-aiders before planning a suitable rescue action. They take few minutes to debate about the most appropriate PHE team (in terms of localization and transportation) they must send on scene. At that time, some firefighters present in the rescue truck take part in the discussion: as they are used to work around the accident area, they know how it is hard to reach for a non-local ambulance driver, even with a map. Finally, an ambulance with civil protection first-aiders, situated near the accident, is sent. One of the firefighters present in the tactical headquarter truck, and familiar with the area, is in radio contact with the ambulance driver to provide him with detailed road explanations. However, once on scene, the ambulance cannot reach the injured person as the peloton is arriving: neither the vehicle nor first-aiders can cross the road, even from the cutting point. The emergency operations commander is worried: "It's the worse situation! The peloton is coming off right now and nothing can be done while they run!'. In effect, the first diagnosis is not always achieved and the FRD tactical headquarter has not enough information to make an appropriate rescue decision. 
At that time, the operational headquarter members meet the FRD tactical headquarter truck to get a better understanding of what is going on and support the decision-making process. Everybody is under pressure and run out of time. The emergency operations commander asks to participants to pinpoint the available ambulances on the map in order to locate where are the closest ambulances to the accident. In doing so, participants mainly direct their attention towards transportation means rather than medical expertise. This is what the head doctor points out: "Don't forget medical means! That's what we need for this case, medical capacities to treat the pain first and handle the patient!". The emergency operations commander agrees, suggesting sending two medical experts vehicles which come from different starting points. However, as the medical vehicles drivers are not familiar with the area, the head doctor immediately notices: "Hey wait! Two vehicles? It's too complicated! Who will guide them? Route is quite difficult! We are going to lose them in the countryside for sure. We won't get there in time!'. They debate and make the decision to send a single medical vehicle, in radio contact with a local firefighter who will guide it if needed. In doing so, decision makers agree to adjust their usual way of doing: due to the first ambulance inability to get to the victim, they cannot follow the firefighters" "graduated response" procedure, that is firstly send first-aiders on scene to establish a first diagnosis and then transport the victim to the advanced medical post or to the hospital for medical care if necessary.

Once on site, medical experts (a doctor and a nurse) complete the life support checking procedure. Regarding the patient medical condition, they request an immediate evacuation to the hospital. In the meantime, the peloton passed, and the first ambulance sent on scene crosses the road from the cutting point to care for the victim. The usual pattern of emergency intervention becomes suitable again.

\section{The Tribehou action situation}

Tribehou is a small city composed of many hamlets and served by small departmental roads. These roads are repeatedly flooded by swamps and can become inaccessible for several days. The nearest hospital is at $20 \mathrm{mn}$ of Tribehou.

July 27, 2016, 12:03 pm. During a medical visit, a general practitioner (GP) examines a patient who suffers from chronic diseases requiring home treatments (a home care assistant spends several hours per day with her). As the medical examination reveals a general health deterioration, he calls the emergency number 15. Debating about the patient diagnosis during few minutes with the emergency regulation doctor, they agree to plan an ambulatory transportation to the nearest hospital. The dispatcher then looks for an available ambulance. As the 
emergency call occurs outside working hours, he first refers to the prefectural list of private ambulances being on call. Seemingly, none can get on the Tribehou sector in time. The dispatcher then turns towards the "Manche" Fire Rescue Department (FRD) with which an agreement has been signed to use its ambulance service when private services are unavailable. This situation is called "ambulance deficiency".

The FRD PHE members are individually called via an identifiable "beep" that means "private ambulance deficiency". A "departure voucher", describing information gathered by the dispatcher, is automatically delivered to the PHE leader (a professional firefighter). He then checks the material, configures the ambulance with regards to the patient expected needs and gather his team. The PHE leader is assisted by two first-aider volunteer firefighters; he knows them and, as he explains, "I know how they work. The division of work is clear between us. When we are together, we are able to anticipate what must be done and we save time". The first volunteer is a municipal officer, in charge of street cleaning, and the second one is a retirement home care assistant.

Teammates go up into the ambulance. They wonder about the real nature of this call that is first identified as a deficiency of private ambulance (the typical "beep") but could be a much more urgent assistance requirement. One of the team members agrees: "You know, sometimes... it's a little bit weird as... you can't be counted on the fact that it's just a problem of unavailability of private ambulance and consider that you have time to go on site, and all that stuff... Sometimes, it's a real and serious rescue mission, not just a transportation issue. Sometimes, things go really wrong for the patient!". The PHE leader adds: "General health deterioration? It's very unclear you know, we will have to diagnose one on site, to guarantee the best possible action". On the way, team members exchange about previous missions. They describe some problems they recently faced with, the solutions they found and ask to each other some advices and answers. The PHE leader also takes advantage of this time to present the Fire and Rescue Centre schedule and activities of the day.

Once at Tribehou, the ambulance driver asks for the patient's address. Giving it to him, the PHE leader suggests a route that he followed three weeks ago during a rescue mission in the same area. The driver makes the decision to choose another itinerary as he recently cleaned the streets and roads of this area and has a good knowledge of road impediments, flooded zones and shortcuts. Once on site, the PHE team is welcomed by the patient's home care assistant. While the two volunteer firefighters go near the patient, the PHE leader asks to the 
care assistant for general information and reads carefully the note left by the GP. He then starts to complete a standardized health scorecard and monitors his team members during the life support checking procedure (complete patient diagnosis). He also asks some questions to the care assistant regarding the patient's medical history, alternating between medical and rescue language: "Hemiplegia? Since when? What did the doctor tell you exactly? What do you think of her health condition today? Have you noticed something unusual? What does it mean to you?". Once the life support checking procedure completed, the PHE leader goes back to the ambulance to reach the emergency's regulation doctor by radio. He passes him through information, using shared standards of radio communication. The doctor allows the transportation to the hospital. The PHE leader doesn't notice a real emergency for this patient case but, as he says: "Anyway, he knows what it is, what the situation is. It's his business as a doctor. And if he has had any doubts, he would have asked me thousands of questions!".

The PHE leader comes back to the patient house and asks to team members to use the stretcher to move the patient into the ambulance, following the usual protocol in this case. While driving to the hospital, the PHE leader updates the team status, using a transmission housing system with which every ambulance is equipped. Status are related to the PHE team situation and localization: on the way to the rescue site, on site, on transfer to the hospital, on the way back to the rescue centre. The language used for up-dating is highly simple and standardized (1 for on the way to the rescue site, 2 for on site, etc.). The up-dated status is automatically delivered to the PHE dispatcher on his tactical screen (red when the PHE team is on operation, green when it is available).

The PHE leader takes advantage of transportation time to review the mission with team members. He considers that life support checking procedures were necessary to efficiently operate on site, to make sure that the patient condition was the same than that expected and to drive her towards the appropriated hospital. Even when emergency interventions seem easy to handle, unforeseen events may appear and create surprise for PHE teams. It's crucial to remain vigilant to deal with the unexpected. The complete patient diagnosis upon arrival is a procedure which allows remaining vigilant and attentive to potential surprise. As one of team members explains: "There is nothing worse than routine. It's the enemy of the rescuer". The ambulance driver agrees and explains that one of the major issues is lack of information regarding the complexity of cases to be treated.

Once arrived at the hospital, the PHE team brings the patient to the emergency triage area while the driver goes back to the ambulance. Following specific procedures, he disinfects the ambulance as well as 
controls and puts tools away so that the team is ready to move again in case of emergency. In the meantime, one of the team members remains with the patient, making sure she is comfortable, while the PHE leader waits for the emergency nurse. A care assistant comes to him to gather information required to welcome the patient. She then calls the nurse and takes the patient in charge, waiting for the emergency doctor who will establish the final diagnosis.

The two PHE team members meet their colleague to help him with the ambulance cleaning. Few minutes later, an emergency nurse runs to them, explaining that she didn't find the time to sign the health scorecard and that she comes to do it just before they leave. The PHE manager reported very carefully the patient health condition (from the medical care at home to her arrival to emergency) in the scorecard. The scorecard is systematically reviewed by the chief of PHE staff who uses it as a monitoring artefact. It plays a key role to assess PHE teams performance.

\section{Discussion and conclusion}

Our article adopts a polycentric perspective to make visible the interconnections between macro-arrangements and coordination practices. This polycentric perspective opens a new space to examine coordination when extreme action teams report to different decisionmaking centres, follow an overarching system of rules, and are collectively engaged in the same collective outcome. In the following, we advance theoretical contributions on one hand, and practical implication both for PHE teams and traditional teams in organisations on the other hand.

\section{Theoretical contributions}

First, our article demonstrates that coordination practices, as manners of coordinating and working, are developed when team members handle action situations "on the spot". Coordination practices are manifold and are combined by actors according to constraints and opportunities they deal with. Our narratives reveal the arrangement of three main coordination practices: anticipation, negotiation and consensual practices.

Anticipation practices allow practitioners to make fast decisions and work safely. They are mainly based on in-depth knowledge of agreements, procedures, artefacts, nature of decision centres and roles distribution which provide practitioners with automatisms, that is internalized suites of procedures/action structuring actors behaviours. Such automatisms support expectancies relevant to tasks, actions and needs of teammates or patients without the need for direct or extended communication (Rico et al., 2008, p. 165). For example, in the Tribehou action situation, the three firefighters (professional and volunteers) 
promptly recognized the typical "beep" for ambulance deficiency and shared its significance: they all agreed to consider that the dispatcher called them as he could not find an available private ambulance, but they also agreed to act as the case to handle was an emergency. In the Utah Beach action situation, all the actors first led towards the graduate response procedure enforcement, without any discussion in this regard. While they were not used to work together and represented different authorities and hierarchical levels, they implicitly directed their effort toward this procedure enforcement. Debates begun when they realized that this procedure was not suited regarding the situation. Extreme team members share an implicit representation and understanding of situations they deal with. As such, anticipation practices can be viewed as a basic component of implicit coordination (e.g. Rico et al., 2008) and team cognition constructs such as team mental and team situation models (Mohammed et al., 2010).

The second coordination practice disclosed by our narratives is negotiation. Negotiation refers to engaging in arguments for and against individual or group positions. Arguments are focused on workability of alternative proposals, and disadvantages of these proposals (Putnam, 1994). Explicit communication is then necessary to exchange and collect suitable information relating to and acting upon urgent situations. In our cases, we observed that practitioners alternated standardized and common languages to communicate. The former is related to a technical body of words and numbers (medical and emergency terms, status transmission, etc.), whereas the later reflects more informal and situated ways of communicating. For example, in the Tribehou action situation, when the PHE leader interacted with the home care assistant, he used very common terms to gather valuable health information: he translated technical medical words into comprehensible wording for a non-expert. We specifically observed practices of negotiation in the Utah Beach action situation, when the operational headquarter members met the FRD tactical headquarter truck to help handling the unexpected turn of the situation. Actors took time to confront the pros and the cons of arguments based on transportation and medical skills. Practices of negotiation are developed when adjustments of usual suites of procedures/action (practices of anticipation) are not enough by themselves to address unclear or unforeseen situations and direct teams toward a relevant solution.

Finally, the third coordination practice surfaced from our narratives is consensus. Consensual practices refer to the achievement of working agreement among members (Peters and Pressey, 2016). They agree on one or more arguments provided during negotiation and create a common view of the way the unexpected must be handled. They 
develop a shared belief and meaning regarding the process to implement and the tasks to perform (Edmondson et al., 2001). The Utah Beach situation illustrates this point when PHE members finally agreed to send a single medical vehicle, in radio contact with a local firefighter who will guide it: practice of consensus led them to elaborate both on transportation and medical skills arguments.

Our article then reveals three main coordination practices extreme action teams articulate to seize opportunities and deal with constraints in the course of action. The remaining question is then how the broader field settings within which these teams are imbedded in is connected to coordination practices?

In paying attention to the overarching of material conditions, rules and procedures, our article secondly contributes in disclosing how these macro-arrangements enable extreme teams to both structure teamwork and dynamically adjust to the unexpected. In effect, macroarrangements provide extreme teams with a template for coordinating. For example, our cases highlight that all actors, no matter their status, hierarchical levels, expertise or institutional affiliation, shared the same medical/paramedical general preferences and core values: apply knowledge and expertise to practice, put into effect procedures to protect patients and improve care, work constructively and rapidly with colleagues and show respect for patients are common objectives and representations of how the pre-hospital work must be completed. Our narratives also illustrated the role played by available technologies and artefacts in structuring teamwork. For example, the permanent emergency assistance map, showing the established "cutting points", was known, shared and used by PHE members to handle the unforeseen situation they faced and find a solution; the transmission housing system used by the PHE leader allowed dispatchers to follow mission advancement and quickly re-allocate human and transportation resources when required; the PHE scorecard aimed at gathering clear and accurate records to both guarantee the patient safety and monitor team performance. Available technologies and artefacts are scrupulously used by team members as they are viewed to support their common efforts of coordinating and making decision (Godé and Lebraty, 2013). Procedures are also salient in our cases. For example, graduate response procedure, ambulance deficiency agreement, first distant diagnosis, life support checking procedure, etc. are viewed as useful by PHE team members. They are implemented by practitioners as their consequences are transparent and they guarantee that the work is carried out in an effective way.

Shared values, procedures, technologies, transportation, codes, maps, etc. act as scaffolding (Okhuysen and Bechky, 2009, p. 474) in offering 
a structure enabling extreme action teams to combine anticipation, negotiation and consensual practices. We consider that macroarrangements shape the routine work of extreme teams in ways that enable them to dynamically coordinate their actions, even if they deviate from the routine when the situation demands it. The structure supports "reworking knowledge to produce a novel action in time to meet the requirements of a given situation" (Mendonca et al., 2001) when extreme teams are confronted to an unexpected turn of event. It creates permanency allowing the development of combinations of coordination practices.

\section{Practical implications}

Finally, our findings suggest some leads for practice, as a polycentric view of coordination offers potential for improving performance both in PHE teams and traditional teams in organisational settings.

The multiplicity of local institutional affiliations nurtures high performance in PHE team coordination. Repeated horizontal and vertical relationships encourage face-to-face discussions and the achievement of common understanding. Action situations are opportunities for teams to self-organize through informal and direct dialogues. Actions situations are temporal spaces, where dynamic adjustments are achieved through the combination of anticipation, negotiation and consensual coordination practices. For each action situation, the structure of macro-arrangements and the dynamic of coordination practices generate a pattern of interactions which supports direct involvement of teams' members in completing collective work. Consequently, polycentric structures must be promoted by PHE authorities instead of monocentric and hierarchical systems (Buttard et al., 2012). Although inherent complexity that may be difficult to understand and conduct for managers, polycentric structure provide more opportunities for PHE teams to manage urgent situations and unexpected turn of event.

However, as shown in the previous section, effective coordination between PHE teams is most likely to be achieved if their members perceived the usefulness of macro-arrangements. Thus, high managers have a key role to play in promoting core values and providing teams with material conditions and procedures aligned with teams needs and expectations. These macro-arrangements must be considered as useful by teams to be implemented.

Extreme teams may be constantly in a state of problem-solving and coordination, which may provide them with an advantage over traditional teams in organisations that only occasionally experience rapidly changing, risky, and/or uncertain contextual demands. However, unexpected events are commonplace in many organisational 
settings (Bechky and Okhuysen, 2011). As stated by Bell et al. (2018), "teams are increasingly being called upon to accomplish critical tasks with high consequences of failure that require effective functioning in complex, dynamic, and unconventional performance environments" ( $\mathrm{p}$. 2764). As extreme teams, traditional teams work in polycentric settings: for example, many stakeholders collaborate in industrial projects, business ecosystems or supply chain. Companies are then challenging with a multiplicity of decision centres and an overarching system of macro-arrangements. A more comprehensive view of the broader settings they are involved in may allow for the development of more accurate team management processes. It is then important for managers to tie teams' successes and failures to larger organisational contexts. A better understanding of micro and macro-connections teams daily work with may help strategic managers to design macro-arrangements able to provide teams both with a permanent template and spaces for agility and flexibility.

Despite its strengths, our findings also have limitations. Future research is needed to determine whether this last practical suggestion is best appropriated to certain types of teams or conditions and how to design suited macro-arrangements for teamwork in more traditional organisation settings. Moreover, our narratives do not enable the examination of the way coordination practices could influence changes in macro-arrangements. There is a need for longitudinal studies that could analyse such effects. Finally, our findings are inextricably tied to the pre-hospital emergency setting. In selecting a qualitative approach and analysis of our data, our results remain highly situated. Although the ethnomethodology investigation refines our understanding of the interconnections between macro-arrangements and coordination practices, our results cannot be generalized. Future research could elaborate on a multiple cases or quantitative analysis to assess our first findings relevance.

\section{References}

ALIGICA P. D. \& TARKO V., "Polycentricity: From Polanyi to Ostrom, and beyond", Governance: An International Journal of Policy, Administration, and Institutions, Vol. 25, $\mathrm{N}^{\circ} 2$, 2012, p.237-262.

BECHKY B. A., "Gaffers, gofers, and grips: Role-based coordination in temporary organizations", Organization Science, Vol. 17, Nº1, 2006, p.3-21.

BECHKY B. A. \& OKHUYSEN G. A., "Expecting the unexpected? How SWAT officers and film crews handle surprises", Academy of Management Journal, Vol. 54, N², 2011, p.239-261. 
BELL S.T., FISHER D.M., BROWN S.G. \& MANN K.E., "An approach for conducting actionable research with extreme teams", Journal of Management, Vol. 47, ํ7, 2018, p.2740-2765.

BOURDIEU P., Le sens pratique, Editions de Minuit, Paris, 1980.

BOUTY I., DRUCKER-GODARD C., GODÉ C., LIEVRE P., NIZET J. \& PICHAULT F., «Les pratiques de coordination en situations extrêmes ", Management \& Avenir, Vol. 10, N41, 2011, p.387-393.

BUTTARD A., DOS SANTOS C. \& TIZIO S., "Networking Healthcare. From a competitive call to a medical cooperation as a guarantee of a found confidence", Recherches en Sciences de Gestion, Vol. 93, $\mathrm{N}^{\circ} 6,2012$, p.21-43.

EDMONDSON A.C., BOHMER R.M. \& PISANO G.P., "Disrupted routines: Team learning and new technology implementation in hospitals", Administrative Science Quarterly, Vol. 46, ํ4, 2001, p.685-716.

FARAJ S. \& XIAO Y., "Coordination in fast-response organizations", Management Science, Vol. 52, Nº, 2006, p.1155-1169.

GARFINKEL H., Studies in ethnomethodology, Englewood Cliffs (NJ): Prentice-Hall, 1967.

GODÉ C. \& LEBRATY J-F., "Experience feedback as an enabler of coordination: An aerobatic military team case", Scandinavian Journal of Management, Vol. 31, $\mathrm{N}^{\circ} 3,2015$, p.324-336.

GODÉ C., Team Coordination in Extreme Environments: Work Practices and Technological Uses Under Uncertainty, John Wiley \& Sons Inc., Hoboken, 2015.

GODÉ C. \& LEBRATY J-F., "Improving decision-making in extreme environment: The case of a military Decision Support System", The International Journal of Technology and Human Interaction, Vol. 9, $\mathrm{N}^{\circ} 1,2013$, p.1-17.

HARRISON S. H. \& ROUSE E. D., "Let's Dance! Elastic coordination in creative group work: A qualitative study of modern dancers", Academy of Management Journal, Vol. 57, N5, 2014, p.1256-1283.

HORVATH I. \& DATRY F., « Point de vue méthodologique pour le développement des entreprises de spectacle vivant», Recherches en Sciences de Gestion, Vol. 94, N 1,2013, p.111-127.

JARZABKOWSKI P., LÊ J. \& FELDMAN M., "Toward a theory of coordinating: Creating coordinating mechanisms in practice", Organization Science, Vol. 23, N4, 2012, p.907-927.

KLEIN K. J., ZIEGERT J. C., KNIGHT A. P. \& XIAO Y., "Dynamic delegation: Shared, hierarchical, and deindividualized leadership in extreme action teams", Administrative Science Quarterly, Vol. 51, Nㅜ, 2006, p.590-621. 
MAJCHRZAK A., JARVENPAA S. L. \& HOLLINGSHEAD A. B., "Coordinating expertise among emergent groups responding to disasters", Organization Studies, Vol. 18, №1, 2007, p.147-161.

MENDONCA D., BEROGGI G. E. G. \& WALLACE W. A., "Decision support for improvisation during emergency response operations", International Journal of Emergency Management, Vol. 1, №1, 2001, p.30-38.

MOHAMMED S., FERZANDI L. \& HAMILTON K., "Metaphor no more: A 15-year review of the Team Mental Model construct", Journal of Management, Vol. 36, $\mathrm{N}^{\circ}$ 4, 2010, p.876-910.

NICOLINI D., GHERARDI S. \& YANOW D., "Introduction: Toward a practice-based view of knowing and learning in organizations", in D. NICOLINI, S. GHERARDI \& D. YANOW (Eds.), Knowing in organizations: a practice-based approach (pp. 3-31), New York: M. E. Sharpe, 2003.

NICOLINI D., "Zooming in and out: Studying practices by switching theoretical lenses and trailing Connections", Organization Studies, Vol. 30, $\mathrm{N}^{\circ} 12,2009$, p.1391-1418.

OKHUYSEN G. \& BECHKY B., "Coordination in organizations: An integrative perspective", The Academy of Management Annals, Vol. 3, $\mathrm{N}^{\circ} 1,2009$, p.463-502.

OSTROM E., "Metropolitan reform: Propositions derived from two traditions", Social Science Quarterly, Vol. 53, N³, 1972, p.474-93.

OSTROM E., Understanding institutional diversity, Princeton: Princeton University Press, 2005.

OSTROM E., "Beyond markets and states: Polycentric governance of complex economic systems", Retrieve from https://www.nobelprize.org/nobel_prizes/economicsciences/laureates/2009/ostrom_lecture.pdf, 2009, p.408-444.

OSTROM E., "Polycentric systems for coping with collective action and global environmental change", Global Environmental Change, Vol. 20, $\mathrm{N}^{\circ} 4,2010$, p.550-557.

OSTROM V., TIEBOUT C. \& WARREN R., "The organization of government in metropolitan areas: A theoretical inquiry", American Political Science Review, Vol. 55, N4, 1961, p.831-842.

OSTROM E. \& WHITAKER G.P., "Does local community control of police make a difference? Some preliminary findings", American Journal of Political Science, Vol. 17, N${ }^{\circ}$, 1973, p.48-76.

OSTROM E., PARKS R. \& WHITAKER G.P., Patterns of Metropolitan Policing, Cambridge, MA.: Ballinger Publishing Company, 1978. 
OSTROM E. \& OSTROM V., Choice, rules and collective action: The Ostroms on the study of institutions and governance, Colchester: ECPR Press, 2014.

PETERS L. \& PRESSEY A., "The co-ordinative practices of temporary organizations", Journal of Business and Industrial Marketing, Vol. 31, No2, 2016, p.301-11.

POLANYI M., The Logic of Liberty, Indianapolis: Liberty Fund, 1951. RECKWITZ A., "Toward a theory of social practices: A development in culturalist theorizing", European Journal of Social Theory, Vol. 5, $\mathrm{N}^{\circ} 2,2002$, p. 243-263.

RICO R., SANCHEZ-MANZANARES M., GIL F. \& GIBSON C., "Team implicit coordination processes: A team knowledge-based approach", Academy of Management Review, Vol. 33, Nº1, 2008, p.163-184.

SCHAKEL J-K., VAN FENEMA P.C. \& FARAJ S., "Shots fired! Switching between practices in police work", Organization Science, Vol. 27, N²2, 2016, p.391-410.

WEICK K. \& SUTCLIFFE K., Managing the unexpected: Resilient performance in an age of uncertainty, San Francisco: Jossey-Bass, 2007.

WOLBERS J., BOERSMA K. \& GROENEWEGEN P., "Introducing a fragmentation perspective on coordination in crisis management", Organization Studies, Vol. 39, N¹1, 2018, p.1521-1546. 